\title{
Lay perspectives on hypertension and drug adherence: systematic review of qualitative research
}

\author{
(c) $(1 \otimes$ OPEN ACCESS
}

\author{
lain J Marshall clinical academic fellow ${ }^{1}$, Charles D A Wolfe professor of public health medicine ${ }^{12}$, \\ Christopher McKevitt reader in social science and health ${ }^{1}$
}

${ }^{1}$ King's College London, Division of Health and Social Care Research, London SE1 3QD, UK; ${ }^{2}$ National Institute for Health Research Comprehensive Biomedical Research Centre, Guy's and St Thomas' NHS Foundation Trust, London, UK

\begin{abstract}
Objective To synthesise the findings from individual qualitative studies on patients' understanding and experiences of hypertension and drug taking; to investigate whether views differ internationally by culture or ethnic group and whether the research could inform interventions to improve adherence.
\end{abstract}

Design Systematic review and narrative synthesis of qualitative research using the 2006 UK Economic and Social Research Council research methods programme guidance.

Data sources Medline, Embase, the British Nursing Index, Social Policy and Practice, and Psyclnfo from inception to October 2011.

Study selection Qualitative interviews or focus groups among people with uncomplicated hypertension (studies principally in people with diabetes, established cardiovascular disease, or pregnancy related hypertension were excluded).

Results 59 papers reporting on 53 qualitative studies were included in the synthesis. These studies came from 16 countries (United States, United Kingdom, Brazil, Sweden, Canada, New Zealand, Denmark, Finland, Ghana, Iran, Israel, Netherlands, South Korea, Spain, Tanzania, and Thailand). A large proportion of participants thought hypertension was principally caused by stress and produced symptoms, particularly headache, dizziness, and sweating. Participants widely intentionally reduced or stopped treatment without consulting their doctor. Participants commonly perceived that their blood pressure improved when symptoms abated or when they were not stressed, and that treatment was not needed at these times. Participants disliked treatment and its side effects and feared addiction. These findings were consistent across countries and ethnic groups. Participants also reported various external factors that prevented adherence, including being unable to find time to take the drugs or to see the doctor; having insufficient money to pay for treatment; the cost of appointments and healthy food; a lack of health insurance; and forgetfulness.
Conclusions Non-adherence to hypertension treatment often resulted from patients' understanding of the causes and effects of hypertension; particularly relying on the presence of stress or symptoms to determine if blood pressure was raised. These beliefs were remarkably similar across ethnic and geographical groups; calls for culturally specific education for individual ethnic groups may therefore not be justified. To improve adherence, clinicians and educational interventions must better understand and engage with patients' ideas about causality, experiences of symptoms, and concerns about drug side effects.

\section{Introduction}

Hypertension is a major health problem in both developed and developing countries and is estimated to cause more than $13 \%$ of deaths annually. ${ }^{1}$ Despite national and international guidelines and initiatives for hypertension, population based studies have found that around two thirds of people with hypertension are either untreated or inadequately controlled, including a substantial number who remain undiagnosed..$^{2-4}$

Among those with a diagnosis of hypertension, the World Health Organization has stated that low adherence to treatment is a key factor impeding good control and has called for research into adherence promoting interventions. ${ }^{5}$ Estimates of the rate of poor adherence or non-adherence to treatment range from $30-50 \%{ }^{6}$ The causes of poor adherence are complex and include complicated drug regimens, the costs of drugs, older age, poor social support, cognitive problems, and depression. ${ }^{7}$

In 2005 a study reviewed the qualitative research on drug taking in a wide range of medical conditions and found that patients often actively decided not to take drugs (intentional non-adherence) rather than unintentionally omitting them. ${ }^{8}$ To date, several patient educational interventions aimed at promoting drug adherence in hypertension have been tested in randomised controlled trials, but most simply informed patients about the importance of adherence and were ineffective. ${ }^{9}$ 
A better understanding of patients' perspectives, through qualitative research, is therefore critical to provide an explanation of the low rates of treatment, adherence, and control and why educational interventions have so far failed, and to inform the development of evidence based interventions to improve management. Indeed, authors of studies of lay epidemiology suggest that clinicians' failure to recognise how people understand disease causation and risk is one of the key obstacles to the success of public health programmes. ${ }^{10-12}$

We carried out a systematic review and narrative synthesis of qualitative studies on hypertension. Specifically, we examined lay understandings about the causes of hypertension and perspectives on drug taking. We also investigated how patients' perspectives varied among different cultures and ethnic groups.

\section{Methods}

We searched electronic databases (Medline, Embase, the British Nursing Index, Social Policy and Practice, and PsycInfo) from inception until October 2011 and hand searched reference lists of relevant papers. The search strategy combined established methodological terms for qualitative research, ${ }^{13}$ with specific terms for hypertension (see supplementary appendix 1).

\section{Study selection}

We included reports of face to face qualitative interviews and focus groups published in peer reviewed journals looking at patient perspectives on hypertension and drug taking; telephone interviews and quantitative questionnaire analyses were excluded. We included studies of people with uncomplicated hypertension and excluded those principally (over 50\%) of people with existing cardiovascular disease or diabetes or who were pregnant. Studies were included regardless of quality. One reviewer (IJM) carried out the search and did an initial screen of titles. Clearly irrelevant titles were excluded at this stage. The remaining abstracts were independently considered for inclusion by two reviewers (IJM and CMcK). Disagreements were resolved by discussion. There was no language limitation for inclusion, and translations were obtained for non-English language papers.

\section{Data synthesis and analysis}

We carried out a narrative synthesis following the steps recommended by the UK Economic and Social Research Council (ESRC) research methods programme guidance. ${ }^{14}$ This was developed to encourage systematic and reproducible approaches to narrative synthesis and promotes transparent reporting and the assessment of the robustness of the results. The guidance provides a toolbox of different methods for reviewers. We used textual summary, tabulation, and thematic analysis to synthesise the results.

\section{Developing a theoretical model}

The narrative synthesis guidance recommends developing a hypothesis before data are collected. ${ }^{14}$ We hypothesised that patients' understanding and experiences of hypertension might contribute to low rates of drug adherence and blood pressure control.

\section{Developing a preliminary synthesis and exploring relations in the data}

IJM used a standard template to extract a textual summary of the populations, research question, and results of the included studies; a sample of these was checked by CMcK. Relations in the data were explored through thematic analysis. IJM and $\mathrm{CMcK}$ independently extracted and organised emerging themes using the "one sheet of paper" method, ${ }^{15}$ using the textual summaries and the full text of papers when needed. A final list of themes and the relations between them was agreed by discussion and consensus. The full text papers were then coded according to the presence or absence of themes. We tabulated these codes by country to examine similarities and variation across cultures.

Qualitative research does not permit statistical inferences: the occurrence of a theme in more than one paper does not imply that it is important or common in the population studied. It may, however, provide a greater degree of certainty that the theme is valid, even if in a few people, and therefore we have reported the number of studies where a particular theme was found.

\section{Assessing the robustness of the synthesis}

We assessed the quality of the included papers using the checklist by Dixon-Woods and colleagues (box). We used specific criteria for each area to give a score out of 11 ; one reviewer (IJM) assessed the quality of each paper. The use of quality assessment when reviewing qualitative research has been debated owing to the lack of agreement among researchers about what criteria should be used, the multitude of possible qualitative methods, and the role of subjective judgment in analysis. ${ }^{16}$ We therefore did not exclude papers with low quality scores but used the scores to provide one indicator of the robustness of the synthesis.

We then carried out two sensitivity analyses by reanalysing the data after removing groups of studies thought to be possible sources of bias. Firstly, we examined whether study quality affected the conclusions by assessing the effect of removing lower quality studies (scoring $<9$ out of 11) from the synthesis. Secondly, to find if the large number of studies in ethnic minority groups had led to unrepresentative conclusions, we carried out a sensitivity analysis only looking at studies that were not in ethnic minority groups.

\section{Results}

Overall, 59 papers reporting 53 qualitative studies met the inclusion criteria (figure $\downarrow$ and table $1 \Downarrow$ ). The studies were from the United States $(n=20)$, the United Kingdom $(n=8)$, Brazil $(n=7)$, Sweden $(n=3)$, Canada $(n=2)$, the Netherlands $(n=2)$, New Zealand $(n=2)$, Denmark $(n=1)$, Finland $(n=1)$, Ghana $(n=1)$, Iran $(n=1)$, Israel $(n=1)$, South Korea $(n=1)$, Spain $(n=1)$, Tanzania $(n=1)$, and Thailand $(n=1)$. Forty studies used one to one qualitative interviews, 11 used focus groups, and two used a mixture of these methods. Twenty four of the 53 studies included people only from ethnic minority groups. Areas covered by study interviews included patients' understanding of the causes, effects, exacerbating factors, and consequences of hypertension; attitudes towards drugs; and the perceived influences of stress, diet, and racism.

\section{Narrative synthesis Causes of hypertension and the role of stress}

The main causes of hypertension reported by participants were stress, food, being overweight, family history, and alcohol (table $2 \Downarrow$ ). Participants widely and strongly connected stress and worries with hypertension: as a cause, an exacerbating factor, and a consequence. A participant from a Dutch study seemed to regard worry and blood pressure as synonymous ${ }^{23}$ : 


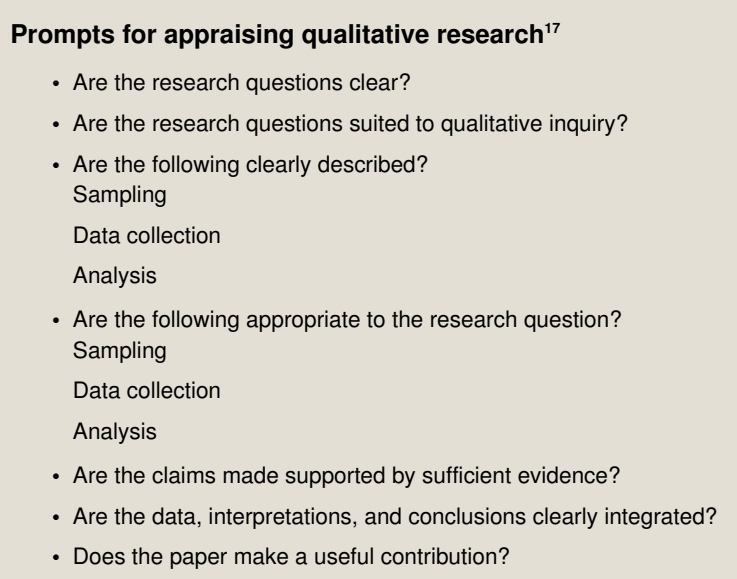

It is the burden of my family. BP [blood pressure] is a sort of ... eh. Actually it doesn't make a difference how you call it: BP or worrying too much; it seems to be the same thing

Stress from work, unemployment, finances, and family matters were often mentioned as impediments to blood pressure control, both directly and indirectly. Most participants reported that stress led directly to increased blood pressure; but leading a stressful life also caused difficulties in finding time to take drugs, eat well, and attend clinic appointments.

Participants from 10 studies (Brazil, Iran, Sweden, United States, and United Kingdom) described reducing or avoiding stress as a consequence of their diagnosis, such as by relaxing, trying to avoid arguments, and changing jobs. ${ }^{18} 324046525456-586468$

In three studies (Ghana and United States) a difficult life with previous long term stresses was thought to be responsible for hypertension. ${ }^{24} 26{ }^{69}$ African-Americans participants in three US studies and Black Caribbean participants in a UK study thought that the stress of experiencing racism was responsible for their high blood pressure. ${ }^{24-26} 4252$

A significant stressful event in the past was thought to be responsible for later hypertension by a few participants in four studies (Ghana, Tanzania, United Kingdom, and United States), ${ }^{24} 426970$ as illustrated by a participant in the UK study: ${ }^{42}$

I was going through a lot of issues at work and I was going through a lot of issues around race and victimisation I was under extreme stress. So, I went to my doctor and that's when I was diagnosed with high blood pressure

In seven studies (Canada, Netherlands, Thailand, United States, and United Kingdom) hypertension was seen by some participants as a temporary or curable condition that would not require long term treatment. 22232852586062

In five studies (Tanzania, United Kingdom, and United States), some participants perceived hypertension to be a distinct condition from high blood pressure, ${ }^{24} 4055670$ highlighted by a participant in a US study ${ }^{40}$ :

My blood just boils, and you don't know what's making it happen. You can't help it. I can't control it, I'm the kind of person who just can't keep my mouth shut for nothing. That pertension can hit you at any time. It's higher and stronger than with pressure. If you have pressure your blood is up, but not as high as with pertension
Most participants understood that hypertension caused serious complications, such as stroke (18 studies: Brazil, Sweden, South Korea, Thailand, United Kingdom, United States), death (13 studies: Brazil, Canada, Denmark, Netherlands, Sweden, United Kingdom, and United States), and heart disease (14 studies: Brazil, Sweden, United Kingdom, and United States). Less widely reported complications included kidney disease (three studies: Brazil, United Kingdom, and United States), paralysis (three studies: Canada and United States), suicide (one study, Brazil), and thinning of the blood (one study, United States). Awareness of possible complications was often a source of fear, as illustrated by a participant in the study from Tanzania ${ }^{70}$ :

I am afraid because I have seen a friend of mine die suddenly. She was overweight and we were living with her in the same house. She woke up in the morning with no problems, ready to leave for work; we talked until the last minute. Suddenly, she fell and died on the spot

Participants in five studies (South Korea, Sweden, United Kingdom, and United States) described that taking drugs reduced anxiety or worries. ${ }^{2048515258}$ This was often thought to be a direct physiological action of drugs $\mathrm{s}^{20} 5152$ but in some cases resulted from feeling protected from the complications of hypertension. ${ }^{48}{ }^{58}$ However, participants in two studies (Sweden and United States) ${ }^{51}{ }^{52}$ negatively perceived drugs to function as sedatives, as illustrated by a participant in the Swedish study ${ }^{51}$ :

Well, that depends basically_no one kind of medication-some doctors give us like the-oh, sedatives out there to make you relax and go to sleep that you can become addicted to. But other than that, I don't think it's much of a dandy, but you have to watch it once you get that sedative type

\section{Symptoms and their meaning}

Participants commonly (13 countries, 27 studies) reported symptoms that they connected with hypertension, particularly headache and dizziness (table $3 \Downarrow$ ). Participants in 16 of the studies reported that hypertension caused them no symptoms. In 11 studies (Brazil, Denmark, Netherlands, New Zealand, Spain, Thailand, United Kingdom, and United States) a large number of participants used the presence or absence of symptoms to indicate whether their blood pressure was raised, ${ }^{21} 222728323757-596572$ as illustrated by a participant in the study from Denmark ${ }^{65}$ :

When I got on medication I felt a change for the better in 14 days ... the headache lifted and I felt 95 percent 
well ... and that's where it's at. It hasn't changed since then. It's not headache, it's a heaviness which makes you constantly aware of the fact that there is something wrong. It's like a chunk of lead swimming around inside the head and I can feel in the teeth and in my gums and when I'm sitting quietly in a chair I can feel the pumping pressure

\section{Attitudes to drug taking}

Participants in nine studies (Brazil, Netherlands, Thailand, United Kingdom, and United States) reported taking drugs regularly according to the prescription. ${ }^{2328} 32334056606473$ A belief that drugs were essential is illustrated by a participant in one of the Brazilian studies ${ }^{64}$ :

\section{It is effective if I take it every day, I can't miss a single day}

A participant in one of the US studies described how she planned to ensure she never ran out of tablets ${ }^{33}$ :

I have to make sure I do it like two weeks in advance to make sure I get there . . I I let the medication get to a certain number of pills and then I'll call them ... get my medication and there won't be a break in between me taking it

\section{Intentional non-adherence: link between hypertension, stress, and symptoms}

Deliberately choosing to avoid or reduce treatment (intentional non-adherence ${ }^{7}$ ) was a theme recurring in many of the studies. People from the Netherlands, the United Kingdom, and the United States (11 studies) reported that symptoms made them more likely to take drugs and lack of symptoms less likely to do so. ${ }^{2122} 27285658$ People from Brazil, Denmark, the Netherlands, Thailand, the United Kingdom, and the United States (10 studies) reported they took drugs exclusively only when symptoms were present. ${ }^{21} 22283237565958606465$ A participant from the Thai study described how he came to restart treatment after a period of feeling well ${ }^{60}$ :
At that period, I did not visit the doctor because I did not have any symptoms. Then I had symptoms again. I had severe headaches, so I went to a hospital . . . after I took medication, my headaches were gone. I recognised that my high blood pressure had not disappeared

A participant in the Canadian study stopped taking drugs as he preferred instead to control blood pressure by reducing stress ${ }^{62}$ :

I dropped them. I didn't last long with them. I said to myself, I'll try to fix my pressure myself. ... I worked with doctors. They told me that I would end up having to take them but I didn't want to. . . . I'm not a big pill-taker

Studies from the Netherlands, Sweden, and the United Kingdom, reported that participants perceived that treatment was not needed at times of reduced stress, with one participant reporting that he didn't take drugs in his home country, where he felt more relaxed. ${ }^{1822} 71$ A quote from the Swedish study illustrates this $^{71}$ :

I use my blood pressure pill after how I feel. So when I'm relaxed and not under any stress like in summer when it's nice weather and vacation, I've never taken any blood pressure pills

\section{Intentional non-adherence: dislike of side effects, fear of addiction}

People widely reported intentionally missing doses (Canada, ${ }^{62}$ Netherlands, ${ }^{22}$ Thailand, ${ }^{60}$ United Kingdom,,${ }^{56}$ and United States $^{33}$ ) or stopping treatment for a time without informing their doctor (Canada, ${ }^{62}$ Denmark, ${ }^{65}$ Spain, ${ }^{37}$ Netherlands, ${ }^{22}$ Thailand,${ }^{60}$ United Kingdom, ${ }^{18} 202856$ and United States ${ }^{31} 334563$ ).

Participants from Spain, the United Kingdom, and the United States experimented with stopping treatment to see how they felt without it. ${ }^{28}{ }^{37}$ Participants from Brazil, Canada, Spain, the United Kingdom, and the United States reported that they self adjusted their drug dose, often because of a desire to avoid side effects or a perception that their blood pressure was controlled. ${ }^{20} 323337565762$ A few participants in two studies (United Kingdom and United States) omitted treatment when using alcohol or recreational drugs owing to fear of a harmful interaction. ${ }^{565763}$

Participants from Canada, Thailand, the United Kingdom, and the United States (in 10 studies) reported a fear of long term problems from taking drugs. ${ }^{18} 20335152565759606273$ These were described as a "build up" of drugs in the body or developing a tolerance or addiction to the drugs. A participant from a UK study described his reluctance to take drugs ${ }^{57}$ :

I prefer to let nature take its course as far as my body is concerned. I' $m$ not one to introduce anything to it if I'm feeling alright. If I'm feeling ill I will take any medication that will make me better or even cure me, but if I feel better I don't see why I should take it, because I don't want to be addicted to nothing other than food and water

Other adverse effects were often reported, such as ankle swelling, lethargy, and urinary frequency. Impotence was mentioned widely by men as a troublesome side effect of treatment (Netherlands, Thailand, United Kingdom, and United States). ${ }^{2022} 315657596073$

\section{Intentional non-adherence: alternative medicines}

Participants from six countries (12 studies) reported supplementing or replacing drugs with a wide range of traditional and alternative medicines (table $4 \Downarrow$ ). Traditional treatments were widely perceived to be safer and more natural than drugs.

\section{Non-intentional non-adherence}

Participants described various external factors that limited their ability to adhere to treatment (non-intentional non-adherence ${ }^{7}$ ). Participants commonly forgot to take drugs from time to time in studies from Canada, South Korea, Spain, the United Kingdom, and the United States (10 studies in total). ${ }^{313437394548626373}$ Participants in eight studies (New Zealand, South Korea, and United States) reported that other commitments meant that they were too busy to take drugs or to attend medical appointments. ${ }^{31} 34394849596374$ Participants from two Brazilian studies and seven of the US studies reported that hypertension care was too expensive: the costs of drugs, healthy food, and visiting doctors were all reported as barriers. ${ }^{32-34} 39404459636476$ Participants in three of the US studies reported that not having health insurance hindered them from accessing medical care. ${ }^{32} 3963$ 


\section{Robustness of findings}

The studies were generally of high quality (mean quality score 9.8 out of 11). Sensitivity analyses were done for the key themes (connecting hypertension with stress, having symptoms, using symptoms to judge blood pressure levels, taking drugs only when symptoms were present). These showed that the principal results were robust when limiting the analysis to the highest quality studies (excluding those scoring $<9$ out of 11 for quality), studies not carried out in an ethnic minority group, and studies done outside the United States (table $5 \Downarrow$ ).

\section{Discussion}

In this systematic review on people's perspectives on hypertension and drug taking, many participants in the individual studies perceived stress to be the primary cause and exacerbating factor of hypertension. They widely described symptoms they perceived to be caused by hypertension, particularly headache, palpitations, and dizziness. Contrary to the conclusions of individual studies, these symptoms were consistent among different ethnic and geographical groups. Notably, these symptoms are also commonly reported as being caused by anxiety in the biomedical literature. ${ }^{77}$

Participants intentionally adjusted their drug dose, took drugs sporadically, and stopped altogether, often without consulting their doctor. Reasons given for reducing treatment included a perception that blood pressure had improved because of a reduction in symptoms, that drugs were unnecessary when under less stress, a dislike of taking drugs, a fear of addiction or tolerance, and side effects.

\section{Comparison with other research on health understanding}

A systematic review in 2005 included 37 qualitative studies looking at drug taking in any medical condition (including four hypertension studies also reported in this review). ${ }^{8}$ That review also found that drugs were seen as undesirable and that many participants feared dependence and tolerance. Participants often tested new drugs for a time to check for adverse effects and whether symptoms were reduced. Our review provides confirmatory evidence from a larger number of studies that these themes are important in hypertension and adds further themes important in hypertension specifically, particularly around stress and symptoms.

Quantitative research provides some evidence that the themes presented here are widespread. A UK study found that $43 \%$ of people used complementary medicine to treat hypertension. ${ }^{78}$ Two US studies found that most participants had symptoms they believed to be caused by hypertension (71-94\% in the first study, $70 \%$ in the second study). ${ }^{79} 80$

\section{Comparison with biomedical model \\ Stress and symptoms}

The nature of the connection between hypertension and stress has been researched extensively. Acute stress has been shown to temporarily increase blood pressure levels. ${ }^{81}$ Evidence from observational studies has also shown that chronic stress can be associated with a sustained rise in high blood pressure. ${ }^{82}$ In the medical literature, however, stress is considered in the context of other important risk factors for hypertension, both modifiable and non-modifiable: age, ethnicity, family history, obesity, a sedentary lifestyle, and alcohol and salt intake. ${ }^{1}$ While participants in our review widely reported avoiding stressful situations, a meta-analysis of randomised controlled trials of relaxation interventions for people with hypertension found that they did not substantially improve blood pressure levels, nor did the trials find good evidence of an effect on cardiovascular disease or mortality. ${ }^{83}$ From the medical perspective, stress plays a small part in hypertension, whereas a recurring theme in the studies presented here was that stress was by far the most important cause.

Likewise, the biomedical literature suggests that symptoms are more likely to be connected with anxiety and stress than blood pressure itself. Although people with hypertension in

observational studies have been found to report symptoms, these studies also found that symptoms did not coincide with periods of raised blood pressure when measured clinically. ${ }^{84} 85$ It was also found that these symptoms were significantly more likely in anxious people. A larger study in the general population found the same association with nervousness, but also found no link with periods of high blood pressure. ${ }^{86}$

\section{Benefits and adverse effects}

Side effects were a widely reported reason for self adjusting or stopping drugs. Participants in these studies described a range of adverse effects of treatment, many of which are listed in the medical literature, including leg swelling, urinary frequency, fatigue, and impotence. ${ }^{87-89}$ Other longer term fears about the drugs, such as the perception of addiction "building up" over time, or acting as sedatives, are not present in the medical literature. A fear of addiction is not exclusive to hypertension: qualitative studies have found that participants with other chronic medical problems reported identical views. ${ }^{8}$ Conversely, participants in several studies in this review reported seeing treatment as essential, stating they would not contemplate missing even a single day. The responses from some participants suggest they thought that treatment abolished any risk of cardiovascular disease. ${ }^{33}$ The benefit assumed by these participants is much greater than the small absolute reductions in risk found in clinical trials. ${ }^{90}$

\section{Overlap with biomedical model}

Rather than being entirely separate, participants' understandings of hypertension overlapped with many aspects of the biomedical model. Aside from the universally strong emphasis placed on stress, the causes and consequences of hypertension reported by participants are identical to those in any medical textbook. The largest included study examined this contradiction in more depth. ${ }^{24}$ In this study individual participants often held mutually contradictory explanations, and the inconsistencies did not trouble them.

\section{Similarities among cultural, ethnic, and geographical groups}

Previous studies have examined the health beliefs of specific ethnic groups; in particular, many have been done in African-American people, to explore cultural factors influencing low rates of hypertension control. ${ }^{91}$ The authors of many of the studies in this review concluded that specific culturally appropriate education is needed, implying that their findings were unique in the particular population studied. However, the principal themes identified here were remarkably similar across geographical and ethnic groups. Participants in most of the studies perceived hypertension as a symptomatic illness associated principally with stress; this was confirmed in the sensitivity analyses looking at studies that were not restricted to minority ethnic groups, and in the non-US studies. 


\section{Differences between cultural, ethnic, and geographical groups}

Racism was often reported by participants from minority ethnic groups. In several studies from the United States of African Americans and one of Filipino-Americans and one study of people of black Caribbean ethnicity in the United Kingdom, the stress caused by racism was reported to exacerbate hypertension. Migrant populations also perceived that they were more likely to have low paying jobs and experience greater economic hardship. African-American participants from two US studies reported a lack of trust of their white doctors, perceiving prejudice against them.

A UK study that compared the reports from black Caribbean and white British participants found that a large number of black Caribbean participants reported self adjusting and stopping drugs, whereas all but one white British participant reported taking drugs regularly. Although a traditional diet was mentioned as an exacerbating factor for hypertension in many studies, this did not seem to be unique to any particular group. A Dutch study found that people of Surinamese, Ghanaian, and white European ethnicity equally thought that their traditional diet worsened their blood pressure. ${ }^{22}$

\section{Implications for clinicians and hypertension education}

The evidence presented here adds weight to the criticism of educational interventions that assume poor adherence is due to patients' failings, either in knowledge or remembering to take drugs. ${ }^{92}$ The participants in the studies presented here did not simply have a knowledge deficit but held alternative explanations for their hypertension; many deliberately chose to avoid drugs.

This may explain why educational interventions that simply inform about the conventional medical view have proved ineffective. ${ }^{9}$ To better deal with these problems, clinicians and educational interventions must acknowledge and incorporate patients' concerns and perspectives. Specifically, patients should be given an honest and accurate representation of the likelihood of benefit and adverse effects with treatment. The evidence of safety of long term use of drugs should be discussed, including that treatment is not thought to "build up" in the body or to cause a physical dependence. Fears about addiction could be further tackled by informing patients that they are unlikely to experience adverse effects if they decide to stop, no matter how long they have taken the treatment. This is in stark contrast to existing educational interventions, which emphasise the importance of continuous tablet taking. ${ }^{9}$

Rather than denying the possibility of symptoms, patients' experiences should be acknowledged. Patients could be informed that people with hypertension often report symptoms but that they have not been found to be a reliable indication of fluctuations in blood pressure levels. Patients could be informed that their risk of cardiovascular disease is increased regardless of whether they have symptoms, and that treatment can effectively prevent cardiovascular disease.

Stress should be placed in the context of other modifiable and non-modifiable risk factors for hypertension and cardiovascular disease; it should be noted that relieving stress alone is not likely to normalise blood pressure and that treatment is recommended at times of high and low stress.

Non-intentional factors, such as forgetting and being busy, were mentioned by many participants as reasons for not taking drugs, and there is low quality evidence from randomised controlled trials that reminder interventions may have an effect. ${ }^{9}$ However, the qualitative research suggests that reminders alone that neglect patients' health understanding are not likely to provide a highly effective solution.

Finally, we did not find strong evidence that educational interventions for hypertension need to be tailored to a particular cultural or ethnic group; the consistency of the results presented here suggests that it is more important to take account of common understandings and experiences across the world.

\section{Strengths and weaknesses of the review}

This study used a systematic strategy for identifying, reporting, and synthesising qualitative research. Several features suggest that the results are robust. Firstly, we identified a large number of studies, which were largely judged to be of high quality. Secondly, many of the themes we identified were reported repeatedly in a large number of papers. These themes did not vary substantially across different countries. Thirdly, the results of sensitivity analyses, when we removed the groups of papers thought possible to cause bias, did not change the conclusions of the main analysis.

We chose to use the Economic and Social Research Council guidance on narrative synthesis as it both encourages transparent reporting and places a strong emphasis on assessing the robustness of results; the lack of both has been a criticism of other methods of synthesising qualitative research. ${ }^{93}$ Although no formal test of different synthesis methods versus each other exists ${ }^{93}$ the strong evidence of themes found here and the large degree of overlap between narrative synthesis and other qualitative synthesis methodologies suggest that other methods would have produced similar results.

We made a pragmatic decision to include studies from peer reviewed journals only, to retrieve the highest quality research. It seems likely that a body of qualitative research also exists in book chapters, university theses, and conference presentations, that was not included in this review. Although we used no language restriction for inclusion of studies and included some non-English language papers, we would have missed those not listed on English language databases.

Certain groups in the research were represented disproportionately: nearly half of the studies looked at an ethnic minority population and nearly half were done in the United States. Although this presented a potential source of bias, the themes in these papers did not differ substantially from those from other countries and from studies without restriction to an ethnic group.

\section{Implications for research}

This review examined the importance of patients' health understanding for one aspect of cardiovascular disease prevention. Syntheses of the qualitative research on other cardiovascular risk factors would complement the findings and could help inform the development of new interventions. Carrying out a systematic review when planning new qualitative research may help to avoid the unintentional examination of questions that have already been extensively researched. Finally, when developing future educational interventions, it may be more rewarding for researchers to consider shared explanations for hypertension rather than attempting to target a specific ethnic or cultural group.

\section{Implications for practice}

Lay perspectives about hypertension are often different from the medical viewpoint: worldwide, people widely perceive that 
hypertension is principally a stress related condition with symptoms and fear addiction or dependence on drugs. These commonly caused people to reduce or stop treatment. If they are to be successful at improving adherence, future educational interventions must incorporate and engage with these widespread perspectives and experiences rather than simply reiterating the biomedical view. A greater understanding between doctors and their patients must play a part in future strategies for reducing cardiovascular disease.

We thank Bom Lee for translating a paper into English and the authors of the original studies who provided copies of their papers.

Contributors: IJM carried out the search, appraised the papers for inclusion, extracted and analysed the data, and drafted the paper. CMcK appraised the papers for inclusion, analysed the data, and critically revised the drafts and the final report. CDAW advised about the study design and methods and critically revised the drafts and the final report. CMcK is guarantor.

Funding: This study is the independent work of the authors.

Competing interests: All authors have completed the ICMJE uniform disclosure form at www.icmje.org/coi_disclosure.pdf (available on request from the corresponding author) and declare: IJM was employed as a clinical editor for Clinical Evidence at BMJ Group from 2008 to March 2010; no other financial relationships with any organisations that might have an interest in the submitted work in the previous three years; no other relationships or activities that could appear to have influenced the submitted work. This article presents independent research commissioned by the National Institute for Health Research under its programme grants for applied research funding scheme (RP-PG-0407-10184). The views expressed in this article are those of the authors and not necessarily those of the National Health Service, the National Institute for Health Research, or the Department of Health. Ethical approval: Not required.

Data sharing: No additional data available.

1 World Health Organization (WHO). The world health report 2002-reducing risks, promoting healthy life. 2011. www.who.int/whr/2002/en/.

2 Falaschetti E, Chaudhury M, Mindell J, Poulter N. Continued improvement in hypertension management in England: results from the Health Survey for England 2006. Hypertension 2009;53480-6.

3 Antikainen RL, Kastarinen MJ, Jousilahti P, Peltonen M, Laatikainen T, Beckett N, et al. Despite evidence-based guidelines, systolic blood pressure remains inadequately controlled in older hypertensive adults. J Hum Hypertens 2010;24:439-46.

4 Hart PD, Bakris GL. Hypertension control rates: time for translation of guidelines into clinical practice. Am J Med 2004;117:62-4

5 World Health Organization. Adherence to long-term therapies: evidence for action. 2010. www.who.int/chp/knowledge/publications/adherence report/en/index.html.

6 Schroeder K, Fahey T, Ebrahim S. How can we improve adherence to blood pressure-lowering medication in ambulatory care?: systematic review of randomized controlled trials. Arch Intern Med 2004;164:722-32.

7 Horne R, Weinman J, Barber N, Elliott R, Morgan M. Concordance, adherence and compliance in medicine taking: a conceptual map and research priorities. National Co-ordinating Centre for NHS Service Delivery and Organisation NCCSDO; 2005. www. medslearning.leeds.ac.uk/pages/documents/useful_docs/76-final-report\%5B1\%5D.pdf.

8 Pound P, Britten N, Morgan M, Yardley L, Pope C, Daker-White G, et al. Resisting medicines: a synthesis of qualitative studies of medicine taking. Soc Sci Med 2005;61:133-55.

9 Glynn L, Fahey T. Cardiovascular medication: improving adherence. Clin Evid (Online) 2011;ii:0220.

10 Bury M. Health promotion and lay epidemiology: a sociological view. Health Care Anal 1994;2:23-30

11 Hunt K, Emslie C. Commentary: the prevention paradox in lay epidemiology—Rose revisited. Int J Epidemiol 2001;30:442-6.

12 Lawlor DA, Frankel S, Shaw M, Ebrahim S, Smith GD. Smoking and ill health: does lay epidemiology explain the failure of smoking cessation programs among deprived populations? Am J Public Health 2003;93:266-70.

13 Shaw R, Booth A, Sutton A, Miller T, Smith JA, Young B, et al. Finding qualitative research: an evaluation of search strategies. BMC Med Res Methodol 2004;4:5.

14 Popay J, Roberts H, Sowden A, Petticrew M, Arai L, Rodgers M, et al. Guidance on the conduct of narrative synthesis in systematic reviews: final report. 2010. www.lancs.ac.uk $\mathrm{shm} / \mathrm{research} / \mathrm{nssr} / \mathrm{research} / \mathrm{dissemination/publications/NS}$ Synthesis Guidance_v1.pdf.

15 Ziebland S, McPherson A. Making sense of qualitative data analysis: an introduction with illustrations from DIPEx (personal experiences of health and illness). Med Educ 2006;40:405-14

16 Dixon-Woods M, Bonas S, Booth A, Jones DR, Miller T, Sutton AJ, et al. How can systematic reviews incorporate qualitative research? A critical perspective. Qual Res 2006;6:27-44.
17 Dixon-Woods M. The problem of appraising qualitative research. Qual Saf Health Care 2004;13:223-5.

18 Bane C, Hughes CM, Cupples ME, McElnay JC. The journey to concordance for patients with hypertension: a qualitative study in primary care. Pharm World Sci 2007;29:534-40.

19 Benson J, Britten N. Patients' decisions about whether or not to take antihypertensive drugs: qualitative study. BMJ 2002;325:873.

20 Benson J, Britten N. What effects do patients feel from their antihypertensive tablets and how do they react to them? Qualitative analysis of interviews with patients. Fam Pract 2006;23:80-7.

21 Beune E, Haafkens J, Meeuwesen L. "Hee broedoe" (hoog bloed): opvattingen over hypertensie van Creools-Surinaamse patiënten in de huisartsenpraktijk. Huisarts Wet 2004:47:25-30.

22 Beune EJ, Haafkens JA, Agyemang C, Schuster JS, Willems DL. How Ghanaian, African-Surinamese and Dutch patients perceive and manage antihypertensive drug treatment: a qualitative study. J Hypertens 2008;26:648-56.

23 Beune EJ, Haafkens JA, Schuster JS, Bindels PJE. 'Under pressure': how Ghanaian, African-Surinamese and Dutch patients explain hypertension. $J$ Hum Hypertens 2006;20:946-55.

24 Blumhagen D. Hyper-tension: a folk illness with a medical name. Cult Med Psychiatry 1980;4:197-224.

25 Boutain DM, Spigner C, Boutain DM, Spigner C. How family, community, and work structured high blood pressure accounts: from African Americans in Washington State. $J$ Holist Nurs 2008;26:173-82.

26 Boutain DM. Discourses of worry, stress, and high blood pressure in rural south Louisiana J Nurs Scholars 2001;33:225-30.

27 Boutin-Foster C, Ogedegbe G, Ravenell JE, Robbins L, Charlson ME. Ascribing meaning to hypertension: a qualitative study among African Americans with uncontrolled hypertension. Ethn Dis 2007;17:29-34.

28 Connell P, McKevitt C, Wolfe C. Strategies to manage hypertension: a qualitative study with black Caribbean patients. Br J Gen Prac 2005;55:357-61.

29 Costa Rdos S, Nogueira LT. Family support in the control of hypertension. Rev Lat Am Enfermagem 2008;16:871-6.

30 Costa e Silva MED, Costa e Silva Barbosa LD, Oliveira AD, Gouveia MT, Nunes BM, Alves EL. [Social representations of women who live with high blood pressure]. Rev Bras Enferm 2008;61:500-7.

31 dela Cruz FA, Galang CB. The illness beliefs, perceptions, and practices of Filipino Americans with hypertension. J Am Acad Nurse Pract 2008;20:118-27.

32 Firmo JOA, Lima-Costa MF, Uchôa E. [The Bambuí Health and Aging Study (BHAS) ways of thinking and acting among hypertensive older adults]. Cad Saude Publica 2004;20:1029-40.

33 Fongwa MN, Evangelista LS, Hays RD, Martins DS, Elashoff D, Cowan MJ, et al. Adherence treatment factors in hypertensive African American women. Vasc Health Risk Manag 2008;4:157-66.

34 Ford CD, Kim MJ, Dancy BL. Perceptions of hypertension and contributing personal and environmental factors among rural Southern African American women. Ethn Dis 2009;19:407-13.

35 Garro LC. Culture and high blood pressure: understandings of a chronic illness in an Ojibwa community. Arctic Med Res 1988;47(suppl 1):70-3.

36 Garro LC. Explaining high blood pressure: variation in knowledge about illness. Am Ethnol 1988;15:98-119.

37 Gascón JJ, Sanchez-Ortuno M, Llor B, Skidmore D, Saturno PJ. Treatment compliance in hypertension study group. Why hypertensive patients do not comply with the treatment: results from a qualitative study. Fam Prac 2004;21:125-30.

38 Greenfield SF, Borkan J, Yodfat Y. Health beliefs and hypertension: a case-control study in a Moroccan Jewish community in Israel. Cult Med Psychiatry 1987;11:79-95.

39 Greer TM. Perceived racial discrimination in clinical encounters among African American hypertensive patients. J Health Care Poor Underserved 2010;21:251-63.

40 Heurtin-Roberts S.'High-pertension'-The uses of a chronic folk illness for personal adaptation. Soc Sci Med 1993;37:285-94.

41 Heurtin-Roberts $S$, Reisin $E$. The relation of culturally influenced lay models of hypertension to compliance with treatment. Am J Hypertens 1992;5:787-92.

42 Higginbottom G. "I didn't tell them. Well, they never ask." Lay understandings of hypertension and their impact on chronic disease management: implications for nursing practice in primary care. $J$ Res Nurs 2008;13:89-99.

43 Higginbottom GM. "Pressure of life": ethnicity as a mediating factor in mid-life and older peoples' experience of high blood pressure. Sociol Health IIIn 2006;28:583-610.

44 Horowitz CR, Tuzzio L, Rojas M, Monteith SA, Sisk JE. How do urban African Americans and Latinos view the influence of diet on hypertension? J Health Care Poor Underserved 2004;15:631-44.

45 Johnson MJ, Williams M, Marshall ES. Adherent and nonadherent medication-taking in elderly hypertensive patients. Clin Nurs Res 1999;8:318-35.

46 Kjellgren KI, Svensson S, AhIner J, Säljö R. Hypertensive patients' knowledge of high blood pressure. Scand J Prim Health Care 1997;15:188-92.

47 Lahdenpera TS, Kyngas HA. Levels of compliance shown by hypertensive patients and their attitude toward their illness. J Adv Nurs 2001;34:189-95.

48 Lee SG, Jeon SY. [The knowledge, attitude and practice of blood pressure management from the patient's viewpoint: a qualitative study]. [Korean]. J Prev Med Public Health/Yebang Uihakhoe Chi 2008;41:255-64

49 Lewis LM, Askie P, Randleman S, Shelton-Dunston B. Medication adherence beliefs of community-dwelling hypertensive African Americans. J Cardiovasc Nurs 2010;25:199-206.

50 Lewis LM. Medication adherence and spiritual perspectives among African American older women with hypertension. A qualitative study. J Gerontol Nurs 2011;37:34-41.

51 Lisper L, Isacson D, Sjödén P-O, Bingefors K. Medicated hypertensive patients' views and experience of information and communication concerning antihypertensive drugs. Patient Educ Couns 1997;32:147-55.

52 Lukoschek P. African Americans' beliefs and attitudes regarding hypertension and its treatment: a qualitative study. $J$ Health Care Poor Underserved 2003;14:566-87.

53 Machado LRC, Car MR. [Dialectics of hypertensive patients' way of life: between the objective and the subjective]. [Portuguese]. Rev Esc Enferm USP 2007;41:573-80.

54 Mohammadi E, Abedi HA, Gofranipour F, Jalali F. Partnership caring: a theory of high blood pressure control in Iranian hypertensives. Int J Nurs Pract 2002;8:324-9.

55 Morecroft C, Cantrill J, Tully MP. Patients' evaluation of the appropriateness of their hypertension management—a qualitative study. Res Social Adm Pharm 2006;2:186-211.

56 Morgan M, Watkins CJ. Managing hypertension: beliefs and responses to medication among cultural groups. Sociol Health IIIn 1988;10:561-78. 


\section{What is already known on this topic}

Between $30 \%$ and $50 \%$ of people with hypertension do not take drugs regularly

Qualitative research in other chronic conditions showed that patients often actively decide to avoid drugs rather than unintentionally missing them

Qualitative studies have focused on the health beliefs of specific ethnic groups in hypertension, suggesting that cultural factors contribute

to low rates of control

\section{What this study adds}

People with hypertension interviewed in qualitative studies often relied on the presence of stress or symptoms to determine whether their blood pressure was raised

This perceived connection led many to reduce or stop drugs in response to fewer symptoms or less stress

There seem to be few major differences in understanding of hypertension between people from different ethnic groups and countries—calls for culturally specific education by the authors of qualitative studies may not be justified

57 Morgan M. The significance of ethnicity for health promotion: patients' use of anti-hypertensive drugs in inner London. Int J Epidemiol 1995;24(suppl 1):S79-84.

58 Ogedegbe G, Mancuso CA, Allegrante JP. Expectations of blood pressure management in hypertensive African-American patients: a qualitative study. $J$ Natl Med Assoc 2004;96:442-9.

59 Ogedegbe G, Harrison M, Robbins L, Mancuso CA, Allegrante JP. Barriers and facilitator of medication adherence in hypertensive African Americans: a qualitative study. Ethn Dis 2004;14:3-12.

60 Panpakdee O, Hanucharurnkul S, Sritanyarat W, Kompayak J, Tanomsup S. Self-care process in Thai people with hypertension: an emerging model. Thai $J$ Nurs Res 2003;7:121-36.

61 Peres DS, Magna JM, Viana LA. [Arterial hypertension patients: attitudes, beliefs, perceptions, thoughts and practices]. [Portuguese]. Rev Saude Publica 2003:37:635-42.

62 Proulx M, Leduc N, Vandelac L, Grégoire JP, Collin J. Social context, the struggle with uncertainty, and subjective risk as meaning-rich constructs for explaining HBP noncompliance. Patient Educ Couns 2007;68:98-106.

63 Rose LE, Kim MT, Dennison CR, Hill MN. The contexts of adherence for African Americans with high blood pressure. J Adv Nurs 2000;32:587-94.

64 Araujo Sadala ML, Messias M, Raujo Sadala ML, Messias Mendes I. Les patients atteints d'hypertension arterielle approche de leur vecu [Patients with arterial hypertension: approach to their experiences]. [French]. Rech Soins Infirm 1998;50-3.

65 Sångren H, Reventlow S, Hetlevik I. Role of biographical experience and bodily sensations in patients' adaptation to hypertension. Patient Educ Couns 2009;74:236-43.

66 Schoenberg NE, Drew EM. Articulating silences: experiential and biomedical constructions of hypertension symptomatology. Med Anthropol Q 2002:16:458-75.

67 Silva C, Vieira M, de Sena R. Meanings and reflections upon being a hypertensive patient. Rev Min Enfermagem 2008;12:346-54.

68 Sims J. What influences a patient's desire to participate in the management of their hypertension? Patient Educ Couns 1999;38:185-94.

69 Spencer J, Phillips E, Ogedegbe G. Knowledge, attitudes, beliefs, and blood pressure control in a community-based sample in Ghana. Ethn Dis 2005:15:748-52.

70 Strahl $\mathrm{H}$. Cultural interpretations of an emerging health problem: blood pressure in Dar es Salaam, Tanzania. Anth Med 2003;10:309-24.

71 Svensson S, Kjellgren KI, Ahlner J, Säljö R. Reasons for adherence with antihypertensive medication. Int J Cardiol 2000;76:157-63.

72 Van Wissen K, Litchfield M, Maling T. Living with high blood pressure. J Adv Nurs 1998;27:567-74.

73 Viswanathan $\mathrm{H}$, Lambert BL. An inquiry into medication meanings, illness, medication use, and the transformative potential of chronic illness among African Americans with hypertension. Res Social Adm Pharm 2005;1:21-39.

74 Wai KC, Elley CR, Nosa V, Kennelly J, Mabotuwana T, Warren J. Perspectives on adherence to blood pressure-lowering medications among Samoan patients: qualitative interviews. J Prim Health Care 2010;2:217-24.

75 Weaver NF, Murtagh MJ, Thomson RG. How do newly diagnosed hypertensives understand "risk"? Narratives used in coping with risk. Fam Prac 2006;23:637-43.

76 Wexler R, Elton T, Pleister A, Feldman D. Barriers to blood pressure control as reported by African American patients. J Natl Med Assoc 2009;101:597-603.
77 Hibbert GA. Ideational components of anxiety: their origin and content. Br J Psychiatry 1984;144:618-24.

78 Gohar F, Greenfield S, Beevers DG, Lip G, Jolly K. Self-care and adherence to medication: a survey in the hypertension outpatient clinic. BMC Complement Altern Med 2008;8:4

79 Meyer D, Leventhal H, Gutmann M. Common-sense models of illness: the example of hypertension. Health Psychol 1985;2:115-35

80 Sharkness CM, Snow DA. The patient's view of hypertension and compliance. Am J Prev Med 1992;8:141-6.

81 Jhalani J, Goyal T, Clemow L, Schwartz JE, Pickering TG, Gerin W. Anxiety and outcome expectations predict the white-coat effect. Blood Press Monit 2005;10:317.

82 Sparrenberger F, Cichelero FT, Ascoli AM, Fonseca FP, Weiss G, Berwanger O, et al. Does psychosocial stress cause hypertension? A systematic review of observational studies. J Hum Hypertens 2008:23:12-9.

83 Dickinson HO, Campbell F, Beyer FR, Nicolson DJ, Cook JV, Ford GA, et al. Relaxation therapies for the management of primary hypertension in adults. Cochrane Database Syst Rev 2008;(1):CD004935.

84 Cantillon P, Morgan M, Dundas R, Simpson J, Bartholomew J, Shaw A. Patients perceptions of changes in their blood pressure. J Hum Hypertens 1997;11:221-5.

85 Chatellier G, Degoulet P, Devries C, Vu HA, Plouin PF, Menard J. Symptom prevalence in hypertensive patients. Eur Heart $J 1982 ; 3$ (suppl C):45-52.

86 Kottke TE, Tuomilehto J, Puska P, Salonen JT. The relationship of symptoms and blood pressure in a population sample. Int $J$ Epidemiol 1979;8:355-9.

87 Joint Formulary Committee. Ramipril. BNF 2001. www.bnf.org.

88 Joint Formulary Committee. Propranolol hydrochloride. BNF 2011. www.bnf.org

89 Jensen J, Lendorf A, Stimpel H, Frost J, Ibsen H, Rosenkilde P. The prevalence and etiology of impotence in 101 male hypertensive outpatients. Am J Hypertens 1999;12:271-5.

90 Wright JM, Musini VM. First-line drugs for hypertension. Cochrane Database Syst Rev 2009;(3):CD001841.

91 Bosworth HB, Dudley T, Olsen MK, Voils Cl, Powers B, Goldstein MK, et al. Racial differences in blood pressure control: potential explanatory factors. Am J Med 2006;119:70.e9-15.

92 Vermeire $E$, Hearnshaw $H$, Van Royen $P$, Denekens J. Patient adherence to treatment: three decades of research. A comprehensive review. J Clin Pharm Ther 2001;26:331-42.

93 Dixon-Woods M, Agarwal S, Jones D, Young B, Sutton A. Synthesising qualitative and quantitative evidence: a review of possible methods. J Health Serv Res Policy 2005;10:45-53.

Accepted: 23 April 2012

\section{Cite this as: BMJ 2012;344:e3953}

This is an open-access article distributed under the terms of the Creative Commons Attribution Non-commercial License, which permits use, distribution, and reproduction in any medium, provided the original work is properly cited, the use is non commercial and is otherwise in compliance with the license. See: http://creativecommons.org/licenses/by$\mathrm{nc} / 2.0 /$ and http://creativecommons.org/licenses/by-nc/2.0/legalcode. 


\section{Tables}

\section{Table 1| Description of included studies}

\begin{tabular}{|c|c|c|c|c|}
\hline Study (country) & Study type & Population & Recruitment site & $\begin{array}{l}\text { Specific ethnic } \\
\text { group interviewed }\end{array}$ \\
\hline $\begin{array}{l}\text { Bane }^{18} \text { (Northern } \\
\text { Ireland) }\end{array}$ & Focus groups & $\begin{array}{l}25 \text { men and women aged } 37-70 \text {; each prescribed } \\
1-5 \text { hypertension drugs }\end{array}$ & Six general practices & NS \\
\hline Benson $^{1920}(\mathrm{UK})$ & Interviews & $\begin{array}{l}28 \text { men and women }(62 \% \text { women), wide age range } \\
\text { reported as frequency table; } 50 \% \text { prescribed } 1 \\
\text { hypertension drug, } 11 \% \text { prescribed } \geq 3 \text { or more }\end{array}$ & Urban general practice & NS \\
\hline Beune $^{21}$ (Netherlands) & Interviews & $\begin{array}{l}15 \text { men and women }(75 \% \text { women) aged } 35-65 \text {; all } \\
\text { prescribed } \geq 1 \text { hypertension drugs in past year, range } \\
\text { not reported }\end{array}$ & Inner city general practices & African-Surinamese \\
\hline Beune $^{2223}$ (Netherlands) & Interviews & $\begin{array}{l}46 \text { men and women aged } 35-65 \text {; all prescribed } \geq 1 \\
\text { hypertension drugs, range not reported }\end{array}$ & Inner city general practices & $\begin{array}{l}\text { Ghanaian, } \\
\text { African-Surinamese, } \\
\text { and white European } \\
\text { ethnicity }\end{array}$ \\
\hline Blumhagen $^{24}$ (USA) & Interviews & $\begin{array}{l}117 \text { men and women (98\% men), all formerly in } \\
\text { armed forces, aged } 22-79 ; \text { drug use not described }\end{array}$ & Primary care centre for military veterans & Majority white \\
\hline Boutain $^{25}$ (USA) & Interviews & $\begin{array}{l}37 \text { men and women aged } 43-88 ; 89 \% \text { prescribed } \geq 1 \\
\text { hypertension drugs }\end{array}$ & $\begin{array}{l}\text { Community social events and word of } \\
\text { mouth }\end{array}$ & African-American \\
\hline Boutain $^{26}$ (USA) & Interviews & $\begin{array}{l}30 \text { men and women, median age } 55 ; 83 \% \text { prescribed } \\
\geq 1 \text { hypertension drugs }\end{array}$ & Rural parish church in south Louisiana & African-American \\
\hline Boutin-Foster ${ }^{27}$ (USA) & Interviews & $\begin{array}{l}60 \text { men and women }(92 \% \text { women) aged } 29-84 \text { with } \\
\text { poorly controlled hypertension; prescribed drug not } \\
\text { reported }\end{array}$ & General practice & African-American \\
\hline Connell $^{28}(\mathrm{UK})$ & Interviews & $\begin{array}{l}19 \text { men and women aged } 40-75 \text {; prescribed drug } \\
\text { not reported }\end{array}$ & Inner city general practice & $\begin{array}{l}\text { Black Caribbean } \\
\text { from Jamaica, } \\
\text { Guyana, and } \\
\text { Trinidad }\end{array}$ \\
\hline Costa $^{29}$ (Brazil) & Interviews & 21 people; ages and prescribed drug not reported & $\begin{array}{l}\text { Hypertension register from primary care } \\
\text { clinic }\end{array}$ & NS \\
\hline Costa e Silva ${ }^{30}$ (Brazil) & Focus groups & 25 women; ages and prescribed drug not reported & $\begin{array}{l}\text { Hypertension register from primary care } \\
\text { clinic }\end{array}$ & NS \\
\hline Dela $\operatorname{Cruz}^{31}$ (USA) & Focus groups & $\begin{array}{l}27 \text { men and women, ages not reported; all } \\
\text { prescribed } \geq 1 \text { hypertension drugs }\end{array}$ & $\begin{array}{l}\text { Four health maintenance organisation } \\
\text { primary care clinics }\end{array}$ & Filipino-American \\
\hline Firmo $^{32}$ (Brazil) & Interviews & $\begin{array}{l}30 \text { men and women aged } \geq 60 \text {; prescribed drug not } \\
\text { reported }\end{array}$ & $\begin{array}{l}\text { Interviewees were subsample of those } \\
\text { taking part in hypertension clinical trial }\end{array}$ & NS \\
\hline Fongwa $^{33}$ (USA) & Focus groups & $\begin{array}{l}20 \text { women aged } 35-68 \text {; all prescribed } \geq 1 \\
\text { hypertension drugs }\end{array}$ & inner-city free primary care clinic & African-American \\
\hline Ford $^{34}$ (USA) & Focus groups & 25 women aged $40-74 ;$ prescribed drug not reported & $\begin{array}{l}12 \text { rural African methodist episcopal } \\
\text { churches }\end{array}$ & African-American \\
\hline Garro $^{35} 36$ (Canada) & Interviews & $\begin{array}{l}29 \text { men and women aged 28-79; prescribed drug } \\
\text { not reported }\end{array}$ & $\begin{array}{l}\text { Chronic disease register at local health } \\
\text { centre and word of mouth }\end{array}$ & Ojibwe \\
\hline Gascon $^{37}$ (Spain) & Focus groups & $\begin{array}{l}44 \text { men and women, ages not reported; all } \\
\text { prescribed } \geq 1 \text { hypertension drugs }\end{array}$ & $\begin{array}{l}\text { Patients of primary care centres, telephone } \\
\text { screened to find non-adherent patients }\end{array}$ & NS \\
\hline Greenfield $^{38}$ (Israel) & Interviews & $\begin{array}{l}22 \text { men and women aged 39-75; prescribed drug } \\
\text { not reported }\end{array}$ & Primary care clinic & Moroccan Jewish \\
\hline Greer $^{39}$ (USA) & Focus groups & $\begin{array}{l}37 \text { men and women aged } 25-68,27 \text { of whom were } \\
\text { prescribed } \geq 1 \text { hypertension drugs }\end{array}$ & $\begin{array}{l}\text { Outpatient clinic with } 21 \% \text { patients } \\
\text { uninsured, } 25 \% \text { covered by Medicaid }\end{array}$ & African-American \\
\hline $\begin{array}{l}\text { Heurtin-Roberts }{ }^{4041} \\
\text { (USA) }\end{array}$ & Interviews & $\begin{array}{l}60 \text { women aged } 45-70 ; \text { all prescribed } \geq 1 \\
\text { hypertension drugs }\end{array}$ & $\begin{array}{l}\text { Outpatient general medical and } \\
\text { hypertension clinics of large public hospital }\end{array}$ & African-American \\
\hline Higginbottom $^{42} 43$ (UK) & $\begin{array}{l}\text { Focus groups and } \\
\text { interviews }\end{array}$ & $\begin{array}{l}36 \text { men and women aged } 37-82 \text {; prescribed drug } \\
\text { not reported }\end{array}$ & $\begin{array}{l}13 \text { general practices with high ethnic } \\
\text { minority populations in Midlands and north } \\
\text { of England }\end{array}$ & Black Caribbean \\
\hline Horowitz ${ }^{44}$ (USA) & Focus groups & $\begin{array}{l}88 \text { men and women, } 34 \% \text { aged }>65 ; \text { prescribed drug } \\
\text { not reported, } 36 \% \text { reported to be uncontrolled }\end{array}$ & $\begin{array}{l}\text { Outpatient clinics in four hospitals in east } \\
\text { and central Harlem }\end{array}$ & $\begin{array}{l}\text { African-American } \\
\text { and Latino American }\end{array}$ \\
\hline Johnson $^{45}$ (USA) & Interviews & $\begin{array}{l}21 \text { men and women aged } 65-92 \text { identified by their } \\
\text { physicians as non-adherent to hypertension drugs }\end{array}$ & $\begin{array}{l}\text { Emergency department (free blood } \\
\text { pressure check service), and from } \\
\text { physician's patient lists }\end{array}$ & African-American \\
\hline
\end{tabular}


Table 1 (continued)

\begin{tabular}{|c|c|c|c|c|}
\hline Study (country) & Study type & Population & Recruitment site & $\begin{array}{l}\text { Specific ethnic } \\
\text { group interviewed }\end{array}$ \\
\hline Kjellgren $^{46}$ (Sweden) & Interviews & $\begin{array}{l}33 \text { men and women aged } 35-83 \text {; all with experience } \\
\text { of taking } \geq 1 \text { hypertension drugs at time of interview } \\
\text { or in past }\end{array}$ & $\begin{array}{l}\text { Half from rural general practice; half from } \\
\text { hypertension specialist clinic in city } \\
\text { hospital }\end{array}$ & NS \\
\hline Lahdenpera $^{47}$ (Finland) & Interviews & $\begin{array}{l}21 \text { men and women aged } 32-63 \text { engaged in trial of } \\
\text { educational intervention, } 2 \text { of whom were prescribed } \\
\geq 1 \text { hypertension drugs }\end{array}$ & $\begin{array}{l}\text { Qualitative interviews of participants in } \\
\text { clinical trial of long term hypertension } \\
\text { educational intervention }\end{array}$ & NS \\
\hline Lee $^{48}$ (South Korea) & Interviews & $\begin{array}{l}26 \text { men and women, all reported to be } \\
\text { non-compliant, aged from } 31 \text { to }>65\end{array}$ & $\begin{array}{l}\text { Public health centre taking part in national } \\
\text { hypertension initiative; private medical } \\
\text { practices, and medical practices looking } \\
\text { after employees of various companies }\end{array}$ & NS \\
\hline Lewis $^{49}$ (USA) & Focus groups & $\begin{array}{l}40 \text { men and women aged } 21-82 \text {, all prescribed } \geq 1 \\
\text { hypertension drugs }\end{array}$ & $\begin{array}{l}\text { Through word of mouth via respected } \\
\text { professionals and community leaders }\end{array}$ & African-American \\
\hline Lewis $^{50}$ (USA) & Interviews & $\begin{array}{l}21 \text { women aged } 57-86 \text {, each prescribed } 1-3 \\
\text { hypertension drugs }\end{array}$ & $\begin{array}{l}\text { Urban multidisciplinary care centre for } \\
\text { elderly people serving principally low } \\
\text { income, frail elderly people }\end{array}$ & African-American \\
\hline Lisper $^{51}$ (Sweden) & Interviews & $\begin{array}{l}21 \text { men and women, ages not reported; all } \\
\text { prescribed } \geq 1 \text { hypertension drugs }\end{array}$ & One urban primary health care centre & NS \\
\hline Lukoschek $^{52}$ (USA) & Focus groups & $\begin{array}{l}42 \text { men and women aged 33-63; separate groups } \\
\text { for participants identified as non-adherent and } \\
\text { adherent to drugs }\end{array}$ & $\begin{array}{l}\text { Primary care clinic at large municipal } \\
\text { hospital serving mostly uninsured or } \\
\text { Medicaid insured patients with low } \\
\text { education levels }\end{array}$ & African-American \\
\hline Machado $^{53}$ (Brazil) & Interviews & $\begin{array}{l}11 \text { men and women, ages not reported; all } \\
\text { prescribed } \geq 1 \text { hypertension drugs }\end{array}$ & Primary care & NS \\
\hline Mohammadi $^{54}$ (Iran) & Interviews & $\begin{array}{l}\text { Number of people and ages unclear; all prescribed } \\
\geq 1 \text { hypertension drugs }\end{array}$ & Recruitment site unclear & NS \\
\hline Morecroft $^{55}(\mathrm{UK})$ & Interviews & $\begin{array}{l}28 \text { men and women aged } 20-78 \text {, all prescribed } \geq 1 \\
\text { hypertension drugs }\end{array}$ & Five general practices in East Midlands & NS \\
\hline $\operatorname{Morgan}^{5657}$ (UK) & Interviews & $\begin{array}{l}60 \text { men and women aged 35-55; } 58 \text { prescribed } \geq 1 \\
\text { hypertension drugs }\end{array}$ & 15 inner city general practices & $\begin{array}{l}\text { Black Caribbean, } \\
\text { and white British }\end{array}$ \\
\hline Ogedegbe $^{58}$ (USA) & Interviews & $\begin{array}{l}93 \text { men and women, mean age } 58 \text {, prescribed mean } \\
\text { of } 2 \text { hypertension drugs; } 60 \% \text { reported as } \\
\text { uncontrolled }\end{array}$ & $\begin{array}{l}\text { Primary care practice in New York } \\
\text { university hospital }\end{array}$ & African-American \\
\hline Ogedegbe $^{59}$ (USA) & $\begin{array}{l}\text { Interviews (some } \\
\text { via telephone) }\end{array}$ & $\begin{array}{l}106 \text { men and women, mean age } 56 \text { (SD 13) years, } \\
\text { prescribed mean of } 2 \text { hypertension drugs }\end{array}$ & $\begin{array}{l}\text { Two primary care practices in New York, } \\
\text { first with diverse population, second } \\
\text { predominantly serving people with low } \\
\text { income }\end{array}$ & African-American \\
\hline Panpakdee $^{60}$ (Thailand) & Interviews & $\begin{array}{l}16 \text { men and women aged } 34-75 ; 96 \% \text { prescribed } \geq 1 \\
\text { hypertension drugs }\end{array}$ & University hospital outpatient clinic & NS \\
\hline Peres $^{61}$ (Brazil) & $\begin{array}{l}\text { Interviews } \\
\text { (semistructured, } \\
\text { content analysis) }\end{array}$ & $\begin{array}{l}32 \text { men and women aged } 37-81 \text {; prescribed } \\
\text { hypertension drug not reported }\end{array}$ & 2 inner city primary care clinics & NS \\
\hline Proulx ${ }^{62}$ (Canada) & Interviews & $\begin{array}{l}27 \text { men and women recruited from adherence study, } \\
\text { each prescribed } 1 \text { hypertension drug }\end{array}$ & $\begin{array}{l}\text { Subsample of participants of larger clinical } \\
\text { trial who identified themselves as } \\
\text { non-adherent }\end{array}$ & NS \\
\hline $\operatorname{Rose}^{63}$ (USA) & Interviews & $\begin{array}{l}19 \text { men aged 33-49 recruited from hypertension } \\
\text { clinical trial }\end{array}$ & $\begin{array}{l}\text { Subsample of participants of larger clinical } \\
\text { trial }\end{array}$ & African-American \\
\hline Sadala $^{64}$ (Brazil) & Interviews & $\begin{array}{l}21 \text { men and women; ages and prescribed drugs not } \\
\text { reported }\end{array}$ & $\begin{array}{l}\text { Those attending an adult health } \\
\text { programme }\end{array}$ & NS \\
\hline Sångren ${ }^{65}$ (Denmark) & Interviews & $\begin{array}{l}17 \text { men and women aged 34-50; prescribed 1-3 } \\
\text { hypertension drugs }\end{array}$ & Four general practices & NS \\
\hline Schoenberg $^{66}$ (USA) & Interviews & $\begin{array}{l}41 \text { men and women aged }>65 \text {; prescribed drug not } \\
\text { reported }\end{array}$ & $\begin{array}{l}\text { Several local churches and local public } \\
\text { health department clinic }\end{array}$ & African-American \\
\hline Silva ${ }^{67}$ (Brazil) & Interviews & $\begin{array}{l}8 \text { men and women; ages and prescribed drugs not } \\
\text { reported }\end{array}$ & $\begin{array}{l}\text { Those attending an adult health } \\
\text { programme }\end{array}$ & NS \\
\hline $\operatorname{Sims}^{68}(\mathrm{UK})$ & Interviews & $\begin{array}{l}49 \text { men and women aged } 38-84 ; 45 \text { of whom were } \\
\text { prescribed } \geq 1 \text { hypertension drugs }\end{array}$ & $\begin{array}{l}\text { General practice in south of England with } \\
\text { nurse led hypertension clinic }\end{array}$ & NS \\
\hline Spencer ${ }^{69}$ (Ghana) & Interviews & $\begin{array}{l}100 \text { men and women; ages reported as categories } \\
\text { from } 18 \text { to > } 75 \text {; prescribed drug not reported }\end{array}$ & $\begin{array}{l}\text { Monthly hypertension clinic at Ghana } \\
\text { Health Mission }\end{array}$ & NS \\
\hline
\end{tabular}


Table 1 (continued)

\begin{tabular}{|c|c|c|c|c|}
\hline Study (country) & Study type & Population & Recruitment site & $\begin{array}{l}\text { Specific ethnic } \\
\text { group interviewed }\end{array}$ \\
\hline Strahl ${ }^{70}$ (Tanzania) & $\begin{array}{l}\text { Focus groups and } \\
\text { interviews }\end{array}$ & $\begin{array}{l}33 \text { men and women in focus groups, } 11 \text { of whom } \\
\text { were interviewed individually; prescribed drug not } \\
\text { reported }\end{array}$ & $\begin{array}{l}\text { Small hypertension and diabetes clinic in } \\
\text { suburb of city }\end{array}$ & NS \\
\hline Svensson $^{71}$ (Sweden) & Interviews & $\begin{array}{l}33 \text { men and women aged } 35-83 \text {, with experience of } \\
\text { taking } \geq 1 \text { hypertension drugs at time of interview or } \\
\text { in past; } 55 \% \text { prescribed } 1 \text { hypertension drug }\end{array}$ & $\begin{array}{l}\text { General practice and specialist } \\
\text { hypertension clinic }\end{array}$ & NS \\
\hline $\begin{array}{l}\text { van Wissen }{ }^{72} \text { (New } \\
\text { Zealand) }\end{array}$ & Interviews & $\begin{array}{l}19 \text { men and women ( } 79 \% \text { women) aged } 41-67 \text {; all } \\
\text { prescribed } \geq 1 \text { hypertension drugs }\end{array}$ & $\begin{array}{l}\text { Register of previous research participants } \\
\text { from Wellington School of Medicine }\end{array}$ & $\begin{array}{l}2 \text { Maori, rest white } \\
\text { European }\end{array}$ \\
\hline Viswanathan ${ }^{73}$ (USA) & Interviews & $\begin{array}{l}20 \text { women, ages presented as categories from } 25 \\
\text { to }>75 ; \text { all prescribed } \geq 1 \text { hypertension drugs }\end{array}$ & Community health centre, Chicago & African-American \\
\hline $\mathrm{Wai}^{74}$ (New Zealand) & Interviews & $\begin{array}{l}20 \text { men and women, } 10 \text { reported to have poor } \\
\text { adherence aged } 41-81 \text {, all prescribed } \geq 1 \\
\text { hypertension drugs; patients with low adherence } \\
\text { and good adherence selected for interview }\end{array}$ & Auckland general practice & Samoan \\
\hline Weaver $^{75}(\mathrm{UK})$ & Interviews & $\begin{array}{l}11 \text { men and women aged } 41-82 \text { with diagnosis of } \\
\text { hypertension in past } 6 \text { months; prescribed drugs not } \\
\text { reported }\end{array}$ & 2 general practices & NS \\
\hline Wexler $^{76}$ (USA) & Focus groups & $\begin{array}{l}26 \text { men and women ( } 77 \% \text { women) aged } 32-71 ; \\
\text { prescribed drug not reported }\end{array}$ & $\begin{array}{l}\text { Patients of Ohio State University primary } \\
\text { care research clinic }\end{array}$ & African-American \\
\hline
\end{tabular}




\section{Table 2| Reported causes of hypertension}

\begin{tabular}{|c|c|}
\hline Perceived causes of hypertension & Countries, studies \\
\hline Stress & 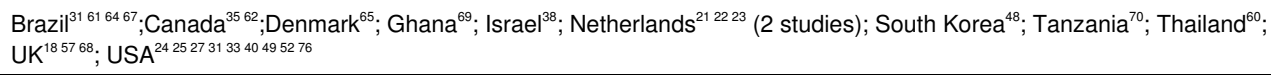 \\
\hline Food & Brazil| $^{32616467} ;$ Canada $^{35}$; Israel ${ }^{38}$; Netherlands ${ }^{2122} ;$ USA $^{2431333441445276} ;$ UK $^{5668}$ \\
\hline Being overweight & Brazili $^{6467} ;$ Netherlands $^{22}$; South Korea ${ }^{48} ;$ Tanzania $^{70} ;$ UK $^{5668} ;$ USA $^{76}$ \\
\hline Family history & Canada $^{35} ;$ Netherlands $^{2122} ;$ USA $^{273340} ;$ Brazil| $^{3267} ;$ South Korea ${ }^{48} ;$ UK $^{56}$ \\
\hline Lack of exercise & Brazil| $^{67}$; Netherlands ${ }^{22} ;$ South Korea ${ }^{48} ;$ USA $^{3176}$ \\
\hline Alcohol & Brazil $^{67} ;$ Canada $^{35} ;$ Netherlands $^{22} ;$ UK $^{5768} ;$ USA $^{24}$ \\
\hline Heat & Brazil $^{32} ;$ Israe ${ }^{38} ;$ Thailand $^{60} ;$ USA $^{24}$ \\
\hline Smoking & Canada $^{35} ;$ UK $^{56} ;$ USA $^{24}$ \\
\hline Pregnancy & Canada $^{35} ;$ Tanzania $^{70}$ \\
\hline Witchcraft/spirits & Canada $^{35}$ Israel $^{38}$ \\
\hline Exposure to cold & Canada $^{35}$ \\
\hline Too much water & $\mathrm{USA}^{24}$ \\
\hline Over-exertion & Canada $^{35}$ \\
\hline Hysterectomy & Canada $^{35}$ \\
\hline Diabetes & Canada $^{35}$ \\
\hline Blood transfusion & Canada $^{35}$ \\
\hline Exposure to farm chemicals & Canada $^{35}$ \\
\hline Eye strain & Canada $^{35}$ \\
\hline Nightmares & Canada $^{35}$ \\
\hline Thick blood & $\mathrm{USA}^{40}$ \\
\hline Blood rising & $\mathrm{USA}^{2440}$ \\
\hline Bad climate & Netherlands $^{23}$ \\
\hline Kidneys & $\mathrm{USA}^{27}$ \\
\hline Resistance to blood flow & $\mathrm{USA}^{27}$ \\
\hline Heart pumping harder & $\mathrm{USA}^{33}$ \\
\hline Too much blood & |srae $^{38}$ \\
\hline
\end{tabular}


Table 3| Symptoms most widely associated with hypertension

\begin{tabular}{|c|c|}
\hline Symptom & Countries (No of studies) \\
\hline Headache & Brazil (4), Canada (1), Denmark (1), Ghana (1), Netherlands (2), South Korea (1), Sweden (2), UK (2), USA (8) \\
\hline Dizziness & $\begin{array}{l}\text { Brazil (3), Canada (1), Denmark (1), Ghana (1), Netherlands (1), New Zealand (1), South Korea (1), Sweden (1), Tanzania (1), Thailand } \\
\text { (1), UK (3), USA (9) }\end{array}$ \\
\hline Palpitations/racing heart & Brazil (3), Canada (1), Netherlands (1), Sweden (1), Tanzania (1), USA (3) \\
\hline Sweating & Brazil (1), Canada (1), Netherlands (1), Tanzania (1), UK (1), USA (1) \\
\hline Tiredness & Brazil (3), Canada (1), Denmark (1), Ghana (1), Sweden (2), UK (1), USA (2) \\
\hline Neck pain & Brazil (3), South Korea (1), Spain (1), USA (2) \\
\hline Nausea/vomiting & Brazil (2), Spain (1), Thailand (1), USA (1) \\
\hline Chest pain & Brazil (2), Canada (1), UK (1), USA (1) \\
\hline Visual changes & Brazil (1), Canada (1), UK (1), USA (4) \\
\hline Feeling nervous/irritable & Brazil (2), USA (2) \\
\hline
\end{tabular}


Table 4| Non-drug treatments reported

\begin{tabular}{ll}
$\begin{array}{l}\text { Country, study } \\
\text { Brazill }^{3261}\end{array}$ & Avocado leaf tea, boldo tea, garlic, lemon balm, passion fruit juice, rosemary, sugar water, tea leaf chayote, water \\
\hline Netherlands ${ }^{2123}$ & $\begin{array}{l}\text { Acupuncture, bush-suporo, blanched celery, coconut bark, cucumber, garlic, garlic tea, homeopathy, neem, papaya leaf, perekese, red cotton, } \\
\text { tamarind, prayer }\end{array}$ \\
\hline Spain $^{37}$ & Lemons, nettle tea \\
\hline Thailand $^{60}$ & Jorn, hed lin cheu, khin chai, meditation, pha talai \\
\hline UK $^{2845657}$ & Aloe vera, banana leaf, "bitters," "blood toner," breadfruit leaf, cerasee, ginseng, green papaya, medina, royal jelly, sorocee tea \\
USA $^{31334052}$ & $\begin{array}{l}\text { Acupuncture, coconut oil, garlic, ginger, guava, guava leaves, herbal teas, home brewed mango leaves, lemons, lime, lemon grass, massage, } \\
\text { noni juice, pito-pito, poltices, prayer }\end{array}$ \\
\hline
\end{tabular}


Table 5| Examples of sensitivity analyses

Theme (group excluded)

Countries, studies

Stress as cause of hypertension:

Excluding studies in specific ethnic groups Brazil ${ }^{32616467} ;$ Canada $^{62} ;$ Denmark $^{65} ;$ Ghana $^{69} ;$ Tanzania $^{70} ;$ Thailand $^{60} ;$ USA $^{24}$

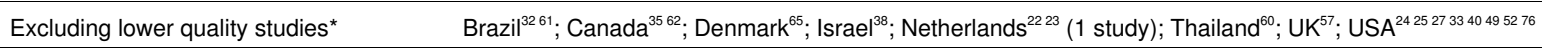

Hypertension causes symptoms:

Excluding studies in specific ethnic groups Brazil ${ }^{32616467} ;$ Denmark $^{65} ;$ Ghana $^{69} ;$ New Zealand $^{72} ;$ South Korea ${ }^{48} ;$ Spain $^{37} ;$ Sweden $^{4671} ;$ Tanzania $^{70} ;$ Thailand $^{60} ;$ UK $^{20}$

Excluding lower quality studies ${ }^{*} \quad$ Brazil $^{3261} ;$ Canada $^{35}$; Denmark ${ }^{65} ;$ Netherlands $^{22}{ }^{23}$ (1 study); New Zealand ${ }^{72}$; South Korea ${ }^{48} ;$ Spain $^{37} ;$ Sweden $^{4671}$; Thailand ${ }^{60} ;$ UK $^{2025567}$ (3 studies); USA 2733344052586366

${ }^{*}$ Quality score $<9 / 11$. 


\section{Figure}

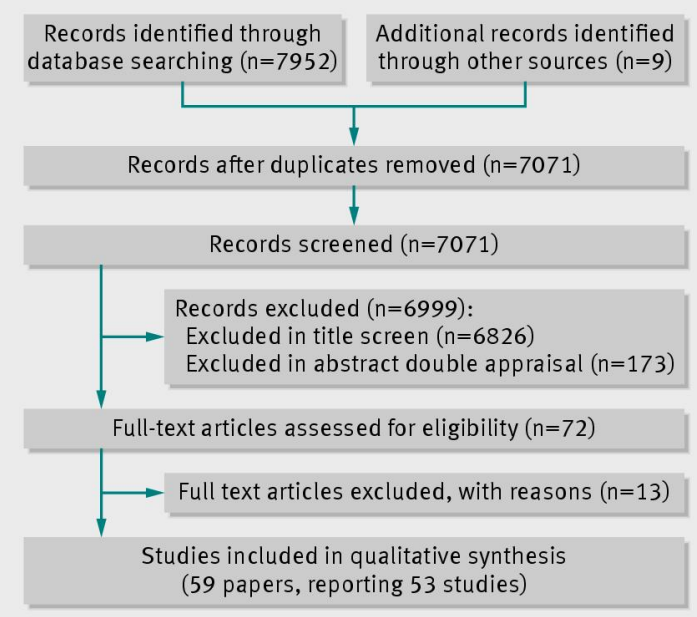

Flow of studies through review 